\title{
Chlorhexidine does not Increase Immediate Bond Strength of Etch-and-Rinse Adhesive to Caries- Affected Dentin of Primary and Permanent Teeth
}

\author{
Tathiane Larissa LENZI ${ }^{1}$ \\ Tamara Kerber TEDESCO ${ }^{1}$ \\ Fabio Zovico Maxnuck SOARES ${ }^{2}$ \\ Alessandro Dourado LOGUERCIO ${ }^{3}$ \\ Rachel de Oliveira ROCHA ${ }^{4}$
}

\begin{abstract}
${ }^{1}$ Department of Orthodontics and Pediatric Dentistry, USP - University of São Paulo, São Paulo, SP, Brazil ${ }^{2}$ Department of Restorative Dentistry, UFSM - Federal University of Santa Maria, Santa Maria, RS, Brazil ${ }^{3}$ Department of Restorative Dentistry, UEPG - University Estadual de Ponta Grossa, Ponta Grossa, PR, Brazil ${ }^{4}$ Department of Stomatology, UFSM - Federal University of Santa Maria, Santa Maria, RS, Brazil
\end{abstract}

\begin{abstract}
The aim of this study was to evaluate the effect of $2 \%$ chlorhexidine digluconate (CHX) on immediate bond strength of etch-andrinse adhesive to sound (SD) and caries-affected (CAD) primary dentin compared with permanent dentin. Flat dentin surfaces from 20 primary molars (Pri) and 20 permanent molars (Perm) were assigned to 8 experimental groups ( $\mathrm{n}=5$ ) according to tooth type (Pri or Perm), dentin condition (SD or CAD - pH-cycling for 14 days) and treatment (control - C or $60 \mathrm{~s}$ application of $2 \% \mathrm{CHX}$ solution after acid etching - CHX). The bonding system (Adper Single Bond 2) was applied according to manufacturer's instructions followed by resin composite application (Filtek Z250). After $24 \mathrm{~h}$ water storage, specimens with cross-section area of $0.8 \mathrm{~mm}^{2}$ were prepared for being tested under microtensile test $(1 \mathrm{~mm} / \mathrm{min})$. Data were submitted to ANOVA and Tukey's post hoc test ( $\alpha=0.05)$. Failure mode was evaluated using a stereomicroscope at $\times 400$. Treatment with $\mathrm{CHX}$ did not result in higher bond strength values than no pretreatment (C groups), independently of tooth type. Primary teeth and caries-affected dentin showed significantly lower ( $\mathrm{p}<0.05)$ bond strength means compared with permanent teeth and sound dentin, respectively. Predominance of adhesive/mixed failure was observed for all groups. CHX did not influence the immediate bond strength to sound or caries-affected dentin of primary and permanent teeth.
\end{abstract}

Key Words: chlorhexidine, bond strength, caries-affected dentin, primary tooth, permanent tooth.

\section{INTRODUCTION}

According to the current concepts of restorative dentistry, ultraconservative treatment approaches are recommended for treating cavited dentin lesions. Therefore, the possibility of greater preservation of dental sound tissue, consequence of the partial removal of carious dentin(1) and of the use of adhesive restorative materials, have instigated the evaluation of bond strength to sound and caries-affected dentin in permanent $(2,3)$ and primary (4-6) teeth.

Previous researches in permanent teeth have reported lower values of bond strength to caries-affected dentin compared with sound dentin $(2,3)$, due to the presence of acid-resistant whitlockite minerals within the dentinal tubules $(2,7)$ and intertubular dentin partially demineralized $(3,8)$. Nevertheless, the results obtained in primary teeth are still controversial (4-6).

Questions also persist in the comparison of the adhesive system's performance between primary and permanent teeth, even in sound substrate. Some studies have shown lower bond strength values to primary dentin $(8,9)$, while others have found similar values (10) or even superior performance in primary dentin (11).

Despite the adequate immediate bond strength, in vivo (12) and in vitro (13) studies have revealed that resindentin bonds deteriorate over time. It has been speculated that a decreasing concentration gradient of resin monomer diffusion within the acid-etched dentin, and a subsequent resin elution from hydrolytically unstable

Correspondence: Tathiane Larissa Lenzi, Departamento de Ortodontia e Odontopediatria, Faculdade de Odontologia, USP, Avenida Prof. Lineu Prestes, 2227, Cidade Universitária, 05508-000 São Paulo, SP, Brasil. Tel/Fax: +55-11-3091-7835. e-mail: tathilenzi@usp.br 
polymeric hydrogels within the hybrid layers (14) leave the exposed collagen fibrils susceptible to hydrolytic and enzymatic degradation, mediated by endogenous metalloproteinases (MMPs) (15). Researchers have demonstrated that chlorhexidine digluconate (CHX) acts as a potent inhibitor of these enzymes $(13,16)$. In addition to minimizing the degradation of resin-dentin bonds, $\mathrm{CHX}$ application should not negatively influence the immediate bond strength, which has already been pointed out in literature $(13,17)$. However, it is unclear in the literature the effect of $\mathrm{CHX}$ in caries-affected dentin (18-20), especially in primary teeth.

Furthermore, since primary and permanent dentin present differences in structure and composition (21), studies are necessary in order to compare the effect of CHX in caries-affected dentin on both substrates. To the best of our knowledge, this is a pioneering investigation of the influence of CHX application on adhesion of etch-and-rise system to caries-affected primary dentin compared with permanent dentin.

The aim of this in vitro study was to evaluate the effect of CHX on immediate bond strength to sound and caries-affected dentin of primary and permanent teeth. The null hypotheses were that: a) CHX has no effect on immediate bond strength to sound or caries-affected dentin; and b) adhesive performance with and without previous CHX application on primary and permanent dentin is not significantly different.

\section{MATERIAL AND METHODS}

\section{Tooth Selection and Preparation}

Ethical approval was obtained by the local Ethics Committee. Forty sound human teeth (20 primary second molars and 20 permanent third molars) were selected and stored in $0.5 \%$ chloramine $\mathrm{T}$ at $4^{\circ} \mathrm{C}$ for 30 days before use. Teeth were assigned to 8 groups $(\mathrm{n}=5)$ according to the tooth type (primary - Pri or permanent - Perm), dentin condition (sound - SD or caries-affected - CAD) and treatment (no pretreatment/control - C or $2 \% \mathrm{CHX}$ application - CHX).

The occlusal enamel was removed with a watercooled diamond disc in a cutting machine (Labcut 1010; Extec Co., Enfield, CT, USA) to obtain flat dentin surfaces. Surrounding enamel was also removed with a diamond bur (\#3195; KG Sorensen, Barueri, SP, Brazil) in a high-speed handpiece with water spray. Exposed occlusal dentin surfaces were then polished with 600- grit silicon carbide paper under running water to create a standardized smear layer.

\section{Artificial Caries-Affected Dentin Induction}

Half of the previously prepared teeth $(n=20)$ were subjected to $\mathrm{pH}$-cycling to create artificial caries-affected dentin. The roots and cervical portions were sealed with epoxy resin (Araldite Hobby; Ciba Especialidades Químicas Ltda, São Paulo, SP, Brazil) and received two layers of an acid-resistant nail polish (Colorama Maybelline Ltda, São Paulo, SP, Brazil).

Specimens were then immersed in $10 \mathrm{~mL}$ of demineralizing solution $(2.2 \mathrm{mM} \mathrm{CaCl} 2,2.2 \mathrm{mM}$ $\mathrm{NaH}_{2} \mathrm{PO}_{4}, 50 \mathrm{mM}$ acetic acid adjusted $\mathrm{pH}$ of 4.8 ) for 8 $\mathrm{h}$ and in the same volume of remineralizing solution (1.5 $\mathrm{mMCaCl}_{2}, 0.9 \mathrm{mM} \mathrm{NaH}_{2} \mathrm{PO}_{4}, 0.15 \mathrm{mM} \mathrm{KCl}$ adjusted $\mathrm{pH}$

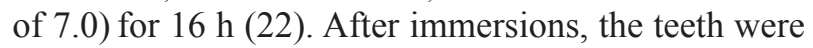
rinsed with deionized water. Solutions were changed every day for 14 days (cycles).

\section{Bonding Procedures}

The flat dentin surfaces were etched with $35 \%$ phosphoric acid gel for $15 \mathrm{~s}$, rinsed with water and dried with an air stream. Dentin surfaces were re-hydrated with $1.5 \mu \mathrm{L}$ of distilled water (C groups) or $1.5 \mu \mathrm{L}$ of $2 \%$ CHX (CHX groups). Solutions were left on the dentin surfaces for $60 \mathrm{~s}$. Excess solutions was removed with absorbent paper and the dentin surfaces were keep moist. Two consecutive coats of the adhesive system (Adper Single Bond 2; 3M ESPE, St. Paul, MN, USA) were applied, gently air dried and light-cured for $10 \mathrm{~s}$. Resin composite buildups (Filtek Z250;3M ESPE) were placed on the bonded surfaces (increments of approximately 1.5 $\mathrm{mm}$ ), which were individually light-cured with a LED unit with $800 \mathrm{~mW} / \mathrm{cm}^{2}$ light intensity (LED Olsen; Olsen Ind. e Com. S/A, Palhoça, SC, Brazil) for $20 \mathrm{~s}$ each.

\section{Microtensile Bond Strength Test ( $\mu$ TBS)}

After storage in distilled water at $37^{\circ} \mathrm{C}$ for $24 \mathrm{~h}$, each tooth was vertically sectioned with a low-speed diamond disc in a cutting machine (Labcut 1010; Extec Co.) to obtain sticks with a cross-sectional area of approximately $0.8 \mathrm{~mm}^{2}$, according to microtensile 'non-trimming' technique.

Specimens were immediately subjected to a microtensile test on a universal testing machine (DL 
2000; Emic, São José dos Pinhais, PR, Brazil) at a crosshead speed of $1 \mathrm{~mm} / \mathrm{min}$.

\section{Failure Mode}

Premature failure was considered as debonded specimens during its preparation that could not be tested.

After the test, all fractured specimens were observed on stereomicroscope with $\times 400$ magnification (HMV II; Shimadzu, Kyoto, KYO, Japan) to determine failure mode: adhesive/mixed (failure at resin/ dentin interface or mixed with cohesive failure of the neighboring substrate) or cohesive (failure exclusively within dentin or resin composite).

\section{Statistical Analysis}

The experimental unit in the current study was the tooth. Thus, the mean of $\mu$ TBS values in MPa of all specimens from the same tooth were averaged for statistical analysis. Premature debonded specimens were included in the statistical analysis (23) and were assigned 4.0 MPa for value to these specimens.

Equality of variances and normal distribution of data were confirmed using the Bartlett and KolmogorovSmirnov tests respectively. Data were subjected to three-way ANOVA (tooth type $\mathrm{x}$ dentin condition $\mathrm{x}$ treatment) and Tukey's post hoc at 5\% significance level. Statistical analysis was carried out with Minitab 16 software package (Minitab Inc., State College, PA, USA). Failure mode data were analyzed descriptively.

\section{RESULTS}

Microtensile bond strength means and standard

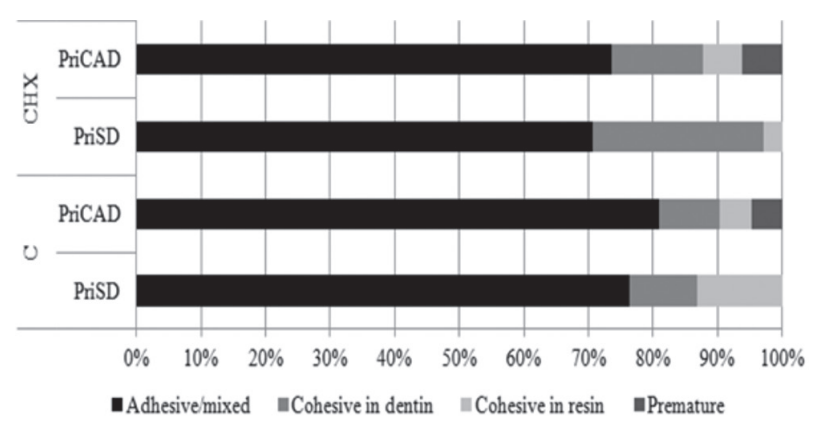

Figure 1. Percentage frequencies of failures for the control and experimental groups of primary teeth. SD: sound dentin. CAD: caries-affected dentin deviations for all groups are summarized in Table 1. Only the main factors tooth type $(\mathrm{p}<0.01)$ and dentin condition $(p<0.01)$ were statistically significant.

CHX application prior to the adhesive system did not influence the bond strength values, since there were no significant differences for CHX and Control groups. However, bond strength values to primary teeth and to caries-affected dentin were significantly lower than those obtained to permanent teeth and to sound dentin, respectively.

\section{Failure Mode}

Figures 1 and 2 present the percentage frequencies of failure modes for experimental groups according to tooth type (primary and permanent). Adhesive/mixed failure was predominant in all experimental groups.

\section{DISCUSSION}

Previous studies $(13,24)$ have shown that

Table 1. Microtensile bond strength means (MPa) and standard deviations for all groups.

\begin{tabular}{lccccc}
\hline \multirow{2}{*}{ Tooth type } & \multicolumn{2}{c}{ Control } & & \multicolumn{2}{c}{ Chorhexidine } \\
\cline { 2 - 3 } \cline { 5 - 6 } & $\mathrm{SD}^{\mathrm{a}}$ & $\mathrm{CAD}^{\mathrm{b}}$ & & $\mathrm{SD}^{\mathrm{a}}$ & $\mathrm{CAD}^{\mathrm{b}}$ \\
\hline Primary $^{\mathrm{A}}$ & $30.8 \pm 2.2$ & $24.5 \pm 3.8$ & & $32.8 \pm 3.8$ & $25.6 \pm 3.6$ \\
Permanent $^{\mathrm{B}}$ & $41.7 \pm 2.7$ & $29.1 \pm 6.0$ & & $43.2 \pm 4.7$ & $36.4 \pm 1.3$ \\
\hline
\end{tabular}

SD: sound dentin. CAD: caries-affected dentin. Different superscript uppercase letters indicate significant difference for tooth type. Different superscript lowercase letters indicate significant difference for dentin condition.

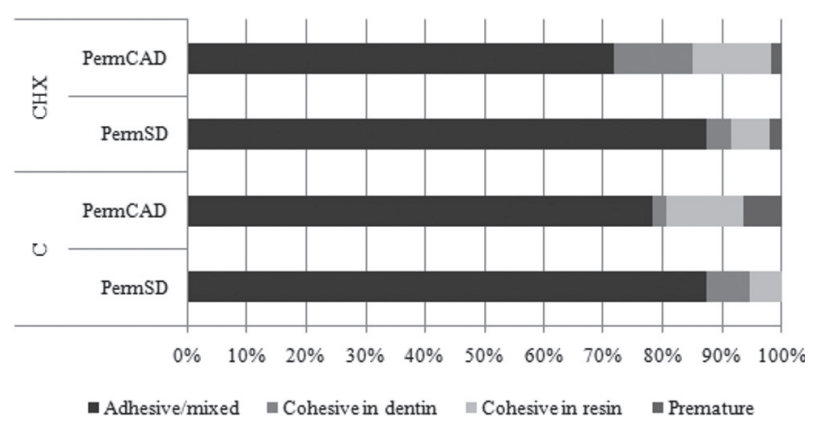

Figure 2. Percentage frequencies of failures for the control and experimental groups of permanent teeth. SD: sound dentin. CAD: caries-affected dentin 
applying the $2 \% \mathrm{CHX}$ after acid etching, in order to minimize the degradation of resin-dentin bonds, does not negatively influence the immediate bond strength to sound permanent dentin. Similar results were observed in the present study in primary teeth, corroborating the findings of Ricci et al. (17). The authors verified that CHX application increased the bond strength of Prime $\&$ Bond NT and Adper Single Bond to the acid-etched sound primary and permanent dentin, while no positive or negative effect was observed for Excite DSC.

Mobarak et al. (20) evaluated the effect of different CHX concentrations on bond strength of self-etch primer adhesive to sound and caries-affected permanent dentin and revealed insignificant differences between control, $2 \%$ and 5\% CHX pretreatment for sound as well as for caries-affected dentin. Komori et al. (19) also observed that the CHX did not affect the immediate bond strength values for a simplified etch-and-rinse adhesive applied in sound or caries-affected dentin. Similar results were found in the present study. Since 2\% CHX application did not affect the immediate bond strength of the tested etch-and-rinse adhesive to sound and caries-affected dentin, the primary null hypothesis was accepted.

However, although CHX application did not influence the bond strength values to sound dentin, it appears that this treatment favors the adhesion to cariesaffected dentin, especially in permanent teeth, since there was a clear upward trend in bond strength values. Unluckily, there is no clear explanation for this issue. As caries-affected dentin has been reported to exhibit increased collagenolytic activity when compared with sound dentin (16), it could be speculated that CHX application could inhibit the degradation of cariesaffected dentin-bonded interfaces in comparison with sound dentin (25). The higher porosity of caries-affected intertubular dentin may help in gaining the benefit of $\mathrm{CHX}$ pretreatment by allowing more penetration of $\mathrm{CHX}$ to deeper layers vulnerable to MMPs. Unfortunately, this phenomenon did not occur in the primary and permanent teeth of the present study, and future investigations can be addressed to test this hypothesis.

Adhesive performance in primary dentin was poor compared with permanent dentin, regardless to use of CHX pretreatment, resulting in the rejection of the second null hypothesis. Considering the great variability in shape, size and depth of natural carious lesions and the difficulty to obtain flat ideal carious dentin surfaces for testing bond strengths, especially in primary teeth, due to reduced thickness of enamel and dentin, often leading to pulp chamber involvement, in this study caries-affected dentin was induced using the protocol suggested by Marquezan et al. (22). It seems to promote a caries-affected dentin layer with superficial demineralization (until $50 \mu \mathrm{m}$ ).

Caries-affected dentin presents physics and chemicals characteristics different of the sound dentin $(2,7)$. Carious intertubular dentin exhibits a higher degree of porosity, due to mineral loss. This will result in a deeper demineralized layer which, after penetration of the adhesive, allows the formation of hybrid layers that are much thicker than those produced in sound dentin (2). This increase in demineralized depth may contribute to the lower $\mu$ TBS values to caries-affected primary and permanent dentin obtained, since resin monomers may not penetrate as deeply as acid in the intertubular dentin.

Differences in composition, tubular density, intrinsic moisture and dentinal permeability (21) between primary and permanent teeth may be responsible for the lower bond strength values obtained in sound primary dentin, which were similar to those of previous studies that also found worst results to primary dentin $(8,9)$.

The results of the present study demonstrate the importance of the substrate on bonding to dentin because the dentin condition (sound and caries-affected) and tooth type (primary and permanent) significantly influenced the bond strength values. Furthermore, whereas pretreatment with $\mathrm{CHX}$ aims to minimize the deleterious action of MMPs on the collagen fibrils exposed at the adhesive interface and in caries-affected dentin, there is a greater exposure of demineralized dentin that is not infiltrated by resin monomers on the bottom of the hybrid layer, and thus further researches are needed to assess the effect of CHX application on the stability of resin-caries-affected dentin, mainly in primary teeth.

In conclusion, CHX did not influence the immediate bond strength to sound or caries-affected dentin of primary and permanent teeth. However, dentin condition and tooth type influenced on bond strength, whereas adhesion to caries-affected dentin was lower than that verified to sound dentin and primary teeth showed lower bond strength than permanent ones.

\section{RESUMO}

O objetivo deste estudo foi avaliar o efeito do digluconato de clorexidina (CHX) a $2 \%$ na resistência de união imediata de adesivo convencional à dentina decídua hígida $(\mathrm{H})$ e afetada pela lesão de cárie (CA) comparada à dentina permanente. 
Superfícies dentinárias planas de 20 molares decíduos (Dec) e 20 molares permanentes (Perm) foram divididas em 8 grupos experimentais $(n=5)$ de acordo com o tipo de dente (Dec ou Perm), condição da dentina (H ou CA - ciclagem de $\mathrm{pH}$ por 14 dias) e tratamento (controle - C ou CHX - aplicação por $60 \mathrm{~s} \mathrm{de}$ solução de digluconato de clorexidina a $2 \%$ após condicionamento ácido). O sistema adesivo (Adper Single Bond 2) foi aplicado de acordo com as instruções do fabricante, seguido da aplicação de resina composta (Filtek Z250). Após 24 h de armazenamento em água, espécimes com área de secção transversal de $0,8 \mathrm{~mm}^{2}$ foram preparados para o teste de microtração ( $1 \mathrm{~mm} / \mathrm{min})$. Os dados foram submetidos à Análise de Variância e teste de Tukey para comparações múltiplas $(\alpha=0,05)$. Modo de falha foi avaliado usando estereomicroscópio com aumento de 400×. Tratamento com CHX não resultou em maiores valores de resistência de união do que sem pré-tratamento ( $\mathrm{C}$ grupos), independente do tipo de dente. Dentes decíduos e dentina afetada apresentaram menores médias de resistência de união em comparação a dentes permanentes e dentina hígida, respectivamente $(\mathrm{p}<0,05)$. Predomínio de falha adesiva/mista foi observado para todos os grupos. CHX não influenciou a resistência de união imediata à dentina hígida ou afetada pela lesão de cárie de dentes decíduos e permanentes.

\section{ACKNOWLEDGEMENTS}

The authors would like to thank CAPES for financial support.

\section{REFERENCES}

1. Banerjee A, Watson TF, Kidd EA. Dentine caries: take it or leave it? Dent Update 2000;27:272-276.

2. Nakajima M, Sano H, Burrow MF, Tagami J, Yoshiyama M, Ebisu $\mathrm{S}$, et al.. Tensile bond strength and SEM evaluation of cariesaffected dentin using dentin adhesives. J Dent Res 1995;74:16791688.

3. Yoshiyama M, Urayama A, Kimochi T, Matsuo T, Pashley DH. Comparison of conventional vs self-etching adhesive bonds to caries-affected dentin. Oper Dent 2000;25:163-169.

4. Hosoya Y, Kawada E, Ushigome T, Oda Y, Garcia-Godoy F. Micro-tensile bond strength of sound and caries-affected primary tooth dentin measured with original designed jig. J Biomed Mater Res B Appl Biomater 2006;77:241-248.

5. Tosun G, Koyuturk AE, Sener Y, Sengun A. Bond strength of two total-etching bonding systems on caries-affected and sound primary teeth dentin. Int J Pediatric Dent 2008;18:62-69.

6. Marquezan M, Osorio R, Ciamponi AL, Toledano M. Resistance to degradation of bonded restorations to simulated caries-affected primary dentin. Am J Dent 2010;23:47-52.

7. Wang Y, Spencer P, Walker MP. Chemical profile of adhesive/ caries-affected dentin interfaces using Raman microspectroscopy. J Biomed Mater Res 2007;81:279-286.

8. Uekusa S, Yamaguchi K, Miyazaki M, Tsubota K, Kurokawa $\mathrm{H}$, Hosoya Y. Bonding efficacy of single-step self-etch systems to sound primary and permanent tooth dentin. Oper Dent 2006;31:569-576.
9. Senawongse P, Harnirattisai C, Shimada Y, Tagami J. Effective bond strength of current adhesive systems on deciduous and permanent dentin. Oper Dent 2004;29:196-202.

10. Soares FZM, Rocha RO, Raggio DP, Sadek FT, Cardoso PEC. Microtensile bond strength of different adhesives systems to primary and permanent dentin. Pediatr Dent 2005;27:457-462.

11. Hosoya Y, Nishiguchi M, Kashiwabara Y, Horiuchi A, Goto G. Comparison of two dentin adhesives to primary vs permanent bovine dentin. J Clin Pediatr Dent 1997;22:69-76.

12. Hashimoto M, Ohno H, Kaga M, Endo K, Sano H, Oguchi H. In vivo degradation of resin-dentin bonds in humans over 1 to 3 years. J Dent Res 2000;79:1385-1391.

13. Carrilho MR, Carvalho RM, de Goes MF, di Hipólito V, Geraldeli $\mathrm{S}$, Tay FR, et al.. Chlorhexidine preserves dentin bond in vitro. J Dent Res 2007;86:90-94.

14. Wang Y, Spencer P. Hybridization efficiency of the adhesivedentin interface with wet bonding. J Dent Res 2003;82:141-145.

15. Pashley DH, Tay FR, Yiu C, Hashimoto M, Breschi L, Carvalho RM, et al.. Collagen degradation by host-derived enzymes during aging. J Dent Res 2004;83:216-221.

16. Hebling J, Pashley DH, Tjäderhane L, Tay FR. Chlorhexidine arrests subclinical degradation of dentin hybrid layers in vivo. J Dent Res 2005;84:741-746.

17. Ricci HA, Sanabe ME, Costa CA, Hebling J. Effect of chlorhexidine on bond strength of two-step etch-and-rinse adhesive systems to dentin of primary and permanent teeth. Am J Dent 2010;23:128-132.

18. Ricci HA, Sanabe ME, de Souza Costa CA, Pashley DH, Hebling J. Chlorhexidine increases the longevity of in vivo resin-dentin bonds. Eur J Oral Sci 2010;118:411-416.

19. Komori PC, Pashley DH, Tjäderhane L, Breschi L, Mazzoni A, de Goes MF, et al.. Effect of $2 \%$ chlorhexidine digluconate on the bond strength to normal versus caries-affected dentin. Oper Dent 2009;34:157-165.

20. Mobarak EH, El-Korashy DI, Pashley DH. Effect of chlorhexidine concentrations on micro-shear bond strength of self-etch adhesive to normal and caries-affected dentin. Am J Dent 2010;23:217-222.

21. Koutsi V, Noonan RG, Horner JA, Simpson MD, Matthees WG, Pashley DH. The effect of dentin depth on the permeability and ultrastructure of primary molars. Pediatr Dent 1994;16:29-35.

22. Marquezan M, Corrêa FN, Sanabe ME, Rodrigues Filho LE, Hebling J, Guedes-Pinto AC, et al.. Artificial methods of dentine caries induction: a hardness and morphological comparative study. Arch Oral Biol 2009;54:1111-1117.

23. Reis A, Loguercio AD, Azevedo CL, de Carvalho RM, Singer JM, Grande RH. Moisture spectrum of demineralized dentin for adhesive systems with different solvent bases. J Adhes Dent 2003;5:183-192.

24. Stanislawczuk R, Amaral RC, Zander-Grande C, Gagler D, Reis $\mathrm{A}$, Loguercio AD. Chlorhexidine-containing acid conditioner preserves the longevity of resin-dentin bonds. Oper Dent 2009;34:481-490.

25. Dayan D, Binderman I, Mechanic GL. A preliminary study of activation of collagenase in carious human dentine matrix. Arch Oral Biol 1983;28:185-187.

Received February 9, 2012 Accepted May 22, 2012 